伯 a 18 de outubro de 2019- Campinas | Brasil

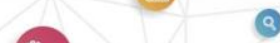

\section{O CINEMA FOI AO POETA: UM PANORAMA CRÍTICO SOBRE A POESIA NO DOCUMENTÁRIO BRASILEIRO CONTEMPORÂNEO}

\section{Sinuhe L. Preto*, Prof. Dr. Gilberto A. Sobrinho.}

\section{Resumo}

Este trabalho debruça-se sobre o documentário brasileiro contemporâneo, com o objetivo de estudar as relações entre poesia e documentário, com foco na imagem do poeta, sua atualização em imagens e sons e uma breve inspeção sobre a maneira como a obra emerge na construção desse olhar. A partir de uma pesquisa que compõe uma breve filmografia geral (e provisória) de documentários sobre poetas, tais filmes foram analisados para entender o modo como o discurso documentário apresenta conceitos e representações sobre os poetas, distinguindo-se, consequentemente, em diferentes abordagens em relação ao poeta como objeto do olhar e da representação.

\section{Palavras-chave:}

cinema e poesia; documentário poético; documentário brasileiro contemporâneo.

\section{Introdução}

Pensar a poesia no documentário brasileiro é entender as condições históricas e culturais que permitiram a confluência entre o campo cinematográfico e o campo literário, considerando quais conceitos foram subsequentes à essa simbiose. O primeiro surto de documentários sobre autores no Brasil aconteceu nos anos 30 e seguiam a linha "documentar para ensinar", curtas-metragens financiados pelo INCE (Instituto Nacional de Cinema Educativo) e dirigidos por Humberto Mauro. A partir dos anos 70, surgem no Brasil documentários experimentais e independentes com 0 ímpeto de uma reelaboração cinematográfica para a construção de uma linguagem afetiva à vida e obra do autor, seguindo modos de subjetivação e metaforização de seu texto. O primeiro filme marcante à época é $O$ poeta do castelo (Figura 1), de Joaquim Pedro de Andrade.

\section{Resultados e Discussão}

Para o início da pesquisa, foram consultados autores como Bill Nichols (2016) e Carl Plantinga (1997) - teóricos do cinema documentário; Ana Cristina Cesar (1999) e Octavio Paz (2012) - teóricos da literatura e poesia; que auxiliaram o desenvolvimento dos conceitos pré-definidos no projeto. Nichols e Plantinga esboçaram modos documentários que serviram para a reflexão no visionamento dos filmes do cinema brasileiro contemporâneo: o modo poético, o modo performático/ vanguardista e o modo reflexivo/metafílmico. Já no campo literário, Octavio Paz orientou a trajetória da poesia moderna para a contemporânea na mistura essencial de Baudelaire, Mallarmé e Rimbaud. E por fim, Ana Cristina César foi a autora fundamental desta pesquisa que tomou como base sua dissertação de mestrado, "Literatura Não É Documento", para entender a figura do poeta metaforizada no cinema com a força de seu próprio texto, e como referência para elaborar uma provisória filmografia contemporânea.

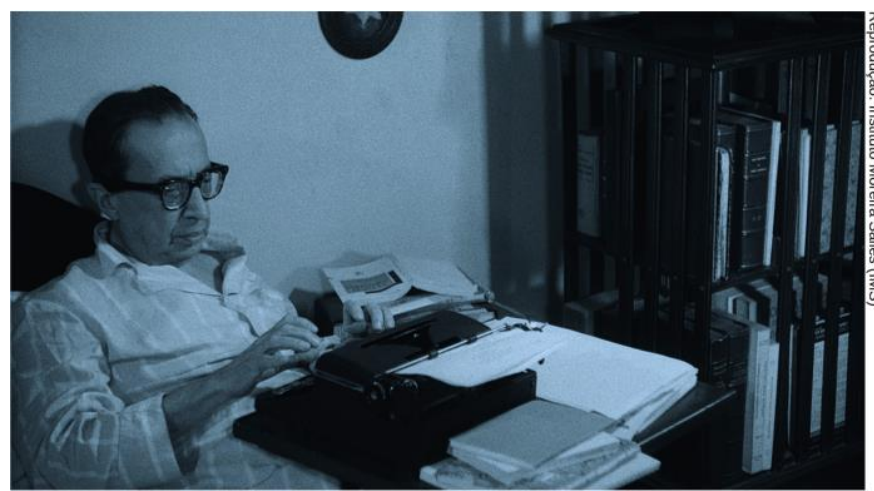

Figura 1 - Manuel Bandeira no filme 0 poeta do castelo (1959).

\section{Conclusões}

Como confirmou Ana C. Cesar, o filme documentário sobre literatura fala mais de literatura na medida em que se identifica ao projeto literário de autonomia e intransitividade de linguagem, ou seja, na medida em que, com toda a sua timidez, fica menos "documentário", livrando-se, como quer a linguagem literária, da obrigação de dizer (ou ensinar) alguma coisa. Logo, reconhecem-se múltiplas possibilidades de se fazer um documentário sobre um poeta, e, portanto, a possibilidade de criar categorias que permitam enquadrá-los para compreender, mesmo que brevemente, como a formulação do discurso de documentários brasileiros sobre poetas tem funcionado, seja através de cinebiografias expositivas, participativas, performativas ou transcriativas, mencionadas numa filmografia provisória de 70 filmes.

CESAR, Ana Cristina. Crítica e tradução. São Paulo, SP: Ática, 1999.
PAZ, Octavio. O arco e a lira: o poema, a revelação poética, poesia e história.

São Paulo, SP: CosacNaify, 2012. PLAZA, Julio. Tradução intersemiótica São Paulo, SP: Perspectiva, 2003. 